\title{
LIVING TEOLOGI: Religiusitas dan Hubungan Sosial Pedagang Kaki Lima
}

\author{
Ahmad Amir Aziz \\ Universitas Islam Negeri Mataram \\ e-mail: ahmadamiraziz@uinmataram.ac.id
}

\begin{abstract}
The study of religious theology has so far been largely focused on doctrinal beliefs. In reality, the implementation of theological beliefs in today's dynamic life is more needed. This paper intends to discuss the concept of living theology and illustrate its practice at the street vendor community. This literature review takes sources from dissertations, research and articles in journals. Mapping is done based on the main issue, which is then carried out the reflective analysis. Thisstudy found that streetvendors have arelativelygood religious basis. Their life spirit becomes a positive force in developing their business. Even though they face different social challenges, they can still build social relationships both internally and externally. Living theology that is seen from the lives of street vendors is work ethic, solidarity and social relations based on wisdom values. The characteristics of social theology are important to be developed, as well as an important ingredient in perfecting the living theology framework being developed.
\end{abstract}

\begin{abstract}
Abstrak. Kajian teologi agama selama ini masih banyak berkutat pada keyakinan yang bersifat doktrinal. Pada kenyataannya, imlpementasi keyakinan teologis dalam kehidupan yang terus berkembang itu lebih dibutuhkan sekarang ini. Tulisan ini bermaksud membahas konsep living teologi dan melihat prakteknya pada komunitas Pedagang Kaki Lima. Riview literatur ini mengambil sumber data dari disertasi, hasil penelitian dan artikel-artikel di jurnal. Pemetaan dilakukan berdasarkan isu utama, yang kemudian dilakukan analisis reflektif. Studi ini menemukan bahwa para PKL memiliki pijakan agama yang relatif cukup. Karena itu pula perlu ditarik garis lurus antara motivasi yang muncul dan basis teologis yang menjadi kekuatan positif dinamika usaha mereka. Meskipun mereka menghadapi tantangan sosial yang berbeda, mereka tetap bisa membangun hubungan sosial yang baik secara internal maupun eksternal. Living teologi yang terlihat dari kehidupan pedagang kaki lima adalah etos kerja, solidaritas dan hubungan sosial berbasis nilai kearifan. Karakteristik teologi sosial tersebut penting dikembangkan, sekaligus sebagai bahan penting penyempurnaan kerangka living teologiyang sedang dikembangkan.
\end{abstract}

Keywords: Living teologi, Religiusitas, Teologi Sosial, Spirit of live, Pedagang Kaki Lima 


\section{A. Pendahuluan}

Agama dan isu-isu sosial masih terus menarik perhatian. Dalam buku Religious Imaginations, ditegaskan pentingnya kekuatan agama untuk menghasilkan visi kolektif yang sangat dibutuhkan untuk mengatasi dilema manusia saat ini. Selain itu juga dikecam adanya demarkasi sekuler agama dari non-agama, yang mengabaikan keterikatan kompleks agama dengan fitur utama lainnya dari kehidupan kontemporer seperti ekonomi, pendidikan, etika, dan politik. $^{1}$

Pemahaman keagamaan, ragam ekspresi dan pengalaman sosial para penganut agama memiliki dinamika yang kompleks, terlebih pada era postmodern yang ambigu dan unpredictable ini. ${ }^{2}$ Suasana ketidakpastian itu membuat banyak orang mengalami kesulitan dalam memahami eksistensi diri dengan lingkungan yang terus berubah. Sebagian orang teralienasi, sebagian lagi tidak kuasa bertarung dengan kerasnya kehidupan. Namun sebagian orang yang memiliki motivasi diri dan keagamaan yang kuat, mereka tetap bertahan dan terus berjuang dengan tegar.

Merespon hal tersebut muncullah sejumlah pandangan. Kalangan developmentalis menilai bahwa sudah menjadi keniscayaan adanya pihak yang terpinggirkan oleh laju modernitas karena mereka tidak memiliki etos dan kompetensi yang memadai. Dalam konteks ini agama dapat berperan penting dalam mendorong progresivitas kelompok yang termarginalkan. Sementara itu, kalangan transformis menilai bahwa orang-orang yang tidak beruntung bukan terjadi akibat kebodohan dan kemalasannya, akan tetapi lebih karena adanya ketimpangan struktur yang menindas. ${ }^{3}$

1 James Walters (ed), Religious Imagination: How Narratives of Faith Are Shaping Today's World (London: Gingko Library, 2018).

2 Anita Sarkar, "We Live in a VUCA World: The Importance of Responsible Leadership," Development and Learning in Organizations 30, no. 3 (2016): 9-12, https://doi.org/10.1108/DL0-07-2015-0062. Istilah populer yang kini berkembang adalah VUCA. Volatility berarti sebuah perubahan yang sangat cepat dalam bidang sosial, ekonomi, politik dan saintek. Uncertainty bermakna sulitnya memprediksi isu dan peristiwa yang akan terjadi. Complexity adalah adanya kerumitan dan mengurai suatu masalah di setiap level. Ambiguity berarti beban berat realitas, sebuah keadaan yang terasa mengambang.

${ }^{3}$ Moeslim Abdurrahman, Islam Transformatif (Jakarta: Pustaka Firdaus, 1997). 
Hal tersebut mendesak untuk terus mendialogkan Islam secara kritis dengan fenomena praksis-kehidupan, sebagai entitas nilai-nilai yang mengatasi ruang dan waktu. Reposisi demikian secara paradigmatik akan membuka kemungkinan lebih besar untuk menghadirkan Islam secara lebih applicable dan compatible dalam setiap konteks perubahan yang terjadi, dengan cara menggeser paradigma dalam berteologi. Teologi yang merupakan bentuk "keyakinan mendalam" akan dapat memberikan inspirasi pada seseorang dan masyarakat untuk mengaktualisasikan diri dengan tepat. Hal ini meniscayakan model teologi yang dapat digunakan sebagai paradigma untuk memaknai kenyataan sekaligus sebagai motivasi religius untuk mentrans-formasikannya.

Atas dasar itu tulisan ini mencoba mengulas konsep living teologi sebagai sebuah perspektif untuk menganalisis potret religiusitas suatu kelompok masyarakat. Gagasan living teologi ini merupakan upaya lanjutan dari pemikiran sebelumnya yang telah menggelorakan konsep teologi pembangunan, teologi kerukunan, teologi pembebasan, teologi sosial, teologi lingkungan hidup, maupun lainnya yang bermuara atau memiliki kaitan erat dengan konsep teologi transformatif. Beberapa studi yang relevan patut disebut berikut ini.

Teologi Trasnformatif Jaringan Islam Liberal (IL) yang ditulis oleh Tasmuji (2011) menyebut upaya JIL untuk mencari sintesis antara pemahaman tekstualis yang bersumber dari ajaran Islam dengan pemahaman liberal dari Barat. Meskipun kenyataannya JIL dianggap berat sebelah, namun wacana yang dikembangkan kelompok ini memiliki segmen dari perguruan tinggi sebagai counter wacana paham literalisme-fundamentalisme yang menguat di masyarakat. ${ }^{4}$

Toha Rudin Rizal (2016) menelaah teologi transformatif sebagai problem solving atas fenomena konflik bermatras agama di Indonesia. Meskipun deskripsi kasus-kasunya yang lebih menonjol dari pada konsep yang hendak dibangun, penelitian tersebut menegaskan bahwa dengan teologi transformatif kelompok-kelompok yang bertikai dapat membebaskan diri dari beban sejarah keagamaan yang acapkali bisa memutarbalikkan fakta dan memerosotkan peran sejati agama. Dengan teologi transformatif ini, keberagamaan manusia akan

4 Tasmuji, “Teologi Transformatif Jaringan Islam Liberal," Teosofi: Jurnal Tasawuf Dan Pemikiran Islam 1, no. 2 (2015): 251, https://doi.org/10.15642/teosofi.2011.1.2.251269.

JURNAL THEOLOGIA — Volume 31, Nomor 1, Juni 2020 
tumbuh baik sebagai proses kreatif dan bertanggung jawab untuk mewujudkan perdamaian. ${ }^{5}$

Siti Robikah (2017) menulis tema serupa dikaitkan dengan aspek sosial umat. Dengan memotret fakta kemiskinan dan probem pendidikan, dia menyebut gerakan transformasi dapat lahir dari sebuah jamaah (kumpulan dari banyak orang) dengan solidaritas baru yang didasarkan pada kesamaan berusaha, keadilan, dan keterbukaan dalam kepemimpinan. Dari embrio itu dapat melahirkan jamaah yang kuat, tangguh, dan memiliki komitmen yang jelas berdasarkan kesamaan visi dan cita-cita bersama. ${ }^{6}$

Junizar Suratman (2019) mengkaji aspek teologis dalam perilaku berdagang Pedagang Kaki Lima. Tulisan ini mengeksplorasi cara melihat dinamika pemahaman kalam berdasarkan masalah-masalah konkret yang mengemuka di masyarakat, khususnya yang dihadapi para PKL di kota Padang. Menurutnya, pemahaman keagamaan yang dimiliki oleh suatuu komunitas tidak terlepas dari apa yang sudah diyakini selama ini berdasarkan kecenderungan aliran tertentu, namun itu bukanlah satu-satunya, karena dinamika kehidupan riil juga turut membentuk pandangan teologis mereka. Temuan yang dihasilkan berupa wawasan profetik sebagai upaya pengembangan diri untuk membebaskan dari berbagai belenggu kemiskinan atau kesenjangan ekonomi.7

Studi-studi di atas mengarah pada upaya melihat fakta-fakta sosial dengan ragam perspektifnya. Berbeda dengan riset-riset sebelumnya, meskipun tetap mengacu padanya, tulisan ini bermaksud memotret lebih dekat pengalaman keberagamaan dan pola hubungan sosial komunitas PKL di berbagai tempat, berdasarkan sumber-sumber kepustakaan yang ada. Perspektif yang digunakan adalah konsep living teologi (baca: living Islamic teologi), yang hingga kini masih

5 Toha Rudin Rizal, "Gambaran Konflik Bermatras Agama Di Indonesia (Problem Solving Berbasis Teologi Transformatif)," El-Hekam 1, no. 1 (2016): 43, https://doi.org/10.31958/jeh.v1i1.336.

6 Siti Robikah, "Membumikan Teologi Transformatif Penyetaraan Sosial Umat," Fikrah: Jurnal Ilmu Aqidah Dan Studi Keagamaan 5, no. 2 (2017): 377-402, https://doi.org/http://dx.doi.org/10.21043/ fikrah.v5i2.2066.

7 Junizar Suratman, Kalam Dan Etos Dagang Refleksi Dimensi Kalam Dan Perilaku Berdagang Pedagang Kaki Lima Di Padang Sumatera Barat (Jakarta: SPS UIN Syarif Hidayatullah, 2019), http://repository.uinjkt.ac.id/dspace/bitstream/123456789/48607/1/JUNIZAR SURATMAN.pdf. 
terus diwacanakan dan dicarikan format epistemologi keilmuannya, terutama dalam konteks integrasi-interkoneksi studi keislaman dengan ilmu-ilmu sosial.

\section{B. Living Teologi: Sebuah Perspektif}

Term living teologi, yang dalam konteks tulisan ini dimaksudkan sebagai Islamic living teologi, memiliki sandaran pada konsep yang lebih luas, living Islam. Sejauh ini living Islam diartikan sebagai "Islam yang hidup di masyarakat" atau "kehidupan Islam di masyarakat". Istilah ini mengemuka sebagai wacana untuk menggulirkan Islam berdasarkan fakta yang hidup di tengah publik, bukan Islam yang termaktub sebagai sebuah doktrin. Sama halnya dengan dua term yang saling diperhadapkan: tekstual vs kontekstual, normatif vs historis. Sebagai sebuah konsep yang sedang tumbuh, gagasan living Islam mengemuka menyusul lahirnya buku-buku dan artikel sejumlah penulis, misalnya Akbar S. Ahmad, Magnus Marsden, Herry Nurdi, dan Fida Sanjakdar. Dari karya-karya tersebut dapat dipahami bahwa living Islam merupakan penggambaran atas keseharian Islam (Islam Today) dalam konteks ruang dan waktu tertentu pada suatu masyarakat.

Dari term tersebut muncul living Qur'an, yang diinterpretasikan sebagai makna yang diberikan masyarakat terhadap al-Qur'an dan bagaimana makna ini diaktualisasikan. Dengan kata lain, ia merupakan "al-Qur'an yang hidup," alQur'an yang mewujud dalam kehidupan sehari-hari mereka. ${ }^{8}$ Jamal Khwaja yang menulis buku Living the Qur'an: In Our Time (2012), berusaha menggabungkan wawasan teologis dan filosofis untuk mempelajari semantik al-Qur'an dan visinya. Karya ini menjelaskan mengapa agama tradisional telah gagal merespon secara memadai terhadap tantangan yang ditimbulkan oleh modernitas. Ia juga berusaha untuk mengenali hubungan intim antara perjuangan umat Islam untuk menjalankan al-Qur'an secara otentik dan banyak dilema etika dan moral yang dihadapi setiap hari dalam kehidupan seseorang. Karya ini mengeksplorasi prinsip-prinsip dasar Islam yang menekankan rasa saling menghormati dan kerja sama di antara semua orang, sehingga membantu menumbuhkan identitas Islam

\footnotetext{
${ }^{8}$ Heddy Shri Ahimsa-Putra, “The Living Qur'ān: Beberapa Perspektif Antropologi,” Walisongo 20, no. 01 (2012): 235-60, https://doi.org/http://dx.doi.org/ 10.21580/ws.20.1.198.
} 
yang hidup dalam lingkungan global multikultural yang saling bergantung dan multibudaya saat ini. ${ }^{9}$

Ada pula konsep living sunnah, yang oleh Fazlur Rahman (1919-1988) sebagai penggagasnya, disebut sebagai sebuah konsep hukum tingkah laku baik fisik ataupan mental. Seperti dikatakannya, "What we want now to do is recast hadith in to living sunnah term by historical interpretation so that we may be able to derive norms from itfor ourselves through an adequate ethical theory and itslegal reembodient"10 Dengan pernyataan ini Rahman menghendaki adanya upaya penuangan kembali hadis-hadis Nabi dalam bentuk living Sunnah Yang dimaksudkannya adalah langkah untuk menghidupkan nilai-nilia hadis ke dalam konsep Sunnah yang mampu mengadaptasi hal-hal baru dan relevan sesuai kebutuhan dan tatangan masyarakat muslim kontemporer.

Istilah living teologi juga sudah lazim digunakan dalam wacana akademik agama-agama. Buku Living Theology in Asia (1982) mengupas pengalaman keagamaan para pastor di beberapa negara kawasan ini dalam menjalankan fungsi religius dan sosialnya. Dari tulisan-tulisan yang ada tampak ada ekspresi untuk mengungkap eksistensi umat Kristiani yang belum menggembirakan, tidak seperti perkembangannya di Eropa. "The Asian Church, for the moment, has no theology of her own, though the cultures that host her teem with them", merupakan pernyataan apa adanya bahwa Gereja di Asia hingga saat ini belum memiliki teologinya sendiri yang mandiri, meskipun budaya yang menjadi tuan rumah berkerabat dengan mereka. Aspirasi dalam buku ini dapat mengundang empati dari kolega mereka di Barat. Apakah akan ada, atau seharusnya, satu "teologi yang hidup di Asia" merupakan pertanyaan teologis yang menarik. Creighton Lacy yang merensi buku itu membuat catatan menarik, yaitu bahwa teologi Asia lebih berhati-hati, lebih tradisional, lebih moderat, dari pada tulisan-tulisan kontemporer dari Afrika atau Amerika Latin. Teologi yang hidup di Asia hanyalah versi lain dari teologi pembebasan, meskipun mereka memiliki kesamaan radikal dalam kepedulian terhadap orang miskin dan tidak berdaya dan penolakan ideologi dominasi dalam semua bentuknya. ${ }^{11}$

\footnotetext{
${ }^{9}$ Jamal Khwaja, Living the Qur'an in Our Time (New Delhi: Sage Publication, 2012).

${ }^{10}$ Fazlur Rahman, Islamic Methodology in History (Islamabad: Islamic Research Institute, 1965), 80.

11 Creighton Lacy, "Book Reviews: Living Theology in Asia Edited by John C. England," Missiology An International Review 11, no. 4 (1983): 535-37, https://doi.org/https://doi.org/10.1177/009182968301100411.
} 
Gambaran di atas menunjukkan bahwa suatu konsep disandingkan dengan term living, dikandung maksud sebagai bentuk pengungkapan atas fenomena aktual yang tengah terjadi, dialami, dihayati, atau diperjuangkan oleh suatu komunitas. Jika living Islam menggambarkan bagaimana Islam Today muncul, dipersepsikan dan diimplentasikan oleh suatu masyarakat pada waktu tertentu, maka living teologi merujuk ke aspek-aspek keyakinan, penghayatan, perasaan, dan pemikiran dalam hidup-keseharian seseorang atau kelompok. Living teologi santri misalnya, dikandung maksud berteologi bersama santri, yang mengasumsikan munculnya kesadaran teologis yang terpicu oleh pergumulan bersama santriyang memiliki aspirasi dan harapan sebagai komunitas pada suatu pesantren. Dengan demikian, santri tidak hanya menjadi obyek dari teologi, tetapi menjadi subyek teologi itu sendiri.

Sebagai suatu konsep yang belum lama muncul, living teologi masih harus menyesuaikan diri dan merangkul disiplin keilmuan yang sudah mapan. Harus diakui, ia belum menjadi suatu konsep atau terminologi keilmuan yang dirumuskan secara utuh, berbeda misalnya dengan antropologi Islam yang relatif lebih utuh dan memiliki basis masyarakat akademis tersendiri. Karenanya untuk cantolan epistemologi keimuan, tema-tema atau isu-isu yang masuk dalam kategori living teologi dapat disematkan ke dalam sub bagian dari Islamic Studies.

Living teologi merupakan bagian dari konsep living Islam secara umum, yaitu suatu perspektif untuk memahami tradisi-tradisi keagamaan yang hidup di masyarakat Muslim yang tidak sekadar apa yang tampak atau hadir dalam tradisi tersebut, tetapi juga apa yang menjadi dasar pijak atau landasan dari tradisi tersebut dimana landasan tersebut telah dibangun sekian lama. ${ }^{12}$ Karenanya konsep living teologi berkaitan dengan dimensi kebudayaan, dalam pengertian sebagai keseluruhan dari gagasan, konsep, pemikiran, keyakinan, perbuatan, ataupun kreasi. Ia berpusat pada pikiran dan perasaan manusia yang selanjutnya dijadikan acuan melakukan tindakan, juga untuk menafsirkan realitas yang dihadapinya.

Berdasarkan hal tersebut, ruang lingkup dan batasan living teologi adalah sebagai berikut. Pertama, dari sisi subyek yang dikaji, dapat mencakup individu,

\footnotetext{
12 H. Zuhri, "Living Islam: Apa Dan Mau Ke Mana?," Living Islam Journal of Islamic Discourses 1, no. 1 (2018): 1-30, https://doi.org/https://doi.org/ 10.14421/lijid.v1i1.1530.
} 
suatu komunitas, maupun masyarakat. Sepanjang mereka masih hidup di alam ini, dan berinteraksi dengan sesama, keberadaannya dapat menjadi subyek studi yang tidak hanya akan bermanfaat bagi dirinya, namun juga untuk orang lain. Kedua, dari sisi obyek, ruang lingkupnya mencakup aspek keyakinan, pemahaman, tradisi, dan implementasinya dalam kehidupan. Berbeda dengan teologi Islam klasik yang fokusnya pada hal-hal yang bersifat ketuhanan, living teologi lebih mengarah pada bentuk konkret pengalaman berteologi dalam dinamika sosial dan kemanusiaan.

\section{Potret Religiusitas dan Hubungan Sosial Pedagang Kaki Lima}

Keberagamaan atau religiusitas mewujud dalam berbagai sisi kehidupan. Ia merupakan kesatuan unsur-unsur yang komprehensif, yang menjadikan seseorang disebut sebagai orang beragama (being religious), dan bukan sekadar mengaku mempunyai agama (having religion). Potret religiusitas Pedagang Kaki Lima (PKL) menggambarkan aktivitas keberagamaan yang bukan hanya pada perilaku ritual, tapi juga ketika mereka melakukan aktivitas usaha yang dijalankan dan juga sikap sosial pada saat berinteraksi dengan yang lain. Unsurunsur motivasi kehidupan, keyakinan pada Yang Ghaib, sikap batiniyah, selukbeluk usaha dan harapan, serta etos sosial, cukup kuat mewarnai pada komunitas PKL. Dengan mendasarkan pada hasil-hasil risetyang ada, pemetaan potret keberagamaan dan hubungan sosial PKL dijelaskan berikut.

\section{Spirit of Life}

Spirit kehidupan mewarnai potret perjalanan komunitas PKL yang tumbuh di kota-kota besar di Indonesia. Umumnya mereka berasal dari warga desa, kemudian tertarik untuk mengadu nasib ke kota. Para pendatang berasal dari wilayah yang "minus" secara ekonomi mencoba memasuki daerah pinggiran perkotaan dengan melakukan aktifitas berjualan. Daya tarik itu cukup kuat terbukti meningkatnya jumlah kaum migran. Faktor daya tarik ekternal ditambah dorongan individual itu menjadi penguat aspek sosial psikologis pendatang. Mereka dikenal memiliki keinginan keras untuk berjuang dan bertahan di kota yang selalu ramai sebagai ladang usahanya.

Semangat hidup tersebut hakekatnya merupakan etos manusiawi, dan bahwa setiap orang beriman menyadari hal tersebut. Meski secara struktural menjadi bagian culture, namun ajaran agama yang melekat dalam diri manusia 
tidak kalah pentingnya. Banyak studi yang menunjukkan bahwa pedagang muslim dalam suatu komunitas memiliki keterkaitan keagamaan yang relatif memadai. Mereka memahami, setiap manusia dapat berusaha mengumpulkan kekayaan dan memanfaatkannya untuk kebutuhan hidup diri dana keluarganya. Junizar menggambarkan corak teolgis atas etos kehidupan para pedagang kaki lima sebagai upaya pengembangan diri sebagai manusia yang berbasis pada kesadaran berketuhanan. Menurutnya, proses pencapaian tersebut diarahkan pada upaya untuk membebaskan diri dari berbagai belenggu kemiskinan atau kesenjangan ekonomi.13 Apa yang dinyatakan Junizar tersebut jelas menunjukkan bahwa aktualisasi etos dagang dari kaum PKL terkandung semangat emansipasi diri yang tak kenal lelah guna menopang kebutuhan hidup dan tuntutan berkarya dalam makna luas.

Spirit of life dari mereka sangat nyata, diperkuat dengan etos komunitas asalnya. Seperti dimaklumi, di negeri kita terdapat sejumlah etnis yang menekuni dunia usaha yang mana mereka hidup di rantauan. Beberapa suku yang terkenal adalah: Minang, Madura dan Bugis. Mereka sangat ulet dalam menekuni usahanya, termasuk berjualan sebagai pedagang kaki lima. Tidak sedikit jumlah mereka yang merantau ke kota-kota yang ada di Indonesia. Etos kerja yang mereka punya bisa diperoleh dari genetik atau pola karena sosial budaya yang melingkupi kehidupan mereka. Bagi orang Madura, tidak ada pekerjaan yang bakal dianggapnya berat, kurang menguntungkan, atau hina, selama kegiatannya bukan tergolong maksiat, sehingga hasilnya akan halal dan diridhoi oleh Allah Swt. Mereka tidak takut kehilangan tanah atau hartanya, akan tetapi mereka sangat takut kehilangan pekerjaannya. ${ }^{14}$

Tampak jelas, etos berdagang, pesan leluhur dan nilai religi menyatu dan menjadi spirit dalam hidup dan bekerja. Bagi mereka, dengan bekerja dan berusaha berarti menghilangkan sifat kemalasan dan menghindari pengangguran. Dengan demikian, melalui kerja berjualan meskipun dengan tenda, gerobak, atau gelaran seadanya, para pedagang kaki lima itu memiliki tujuan ganda yaitu ukhrawi dan duniawi. Dalam tujuan ukhrawi ingin

13 Suratman, Kalam Dan Etos Dagang Refleksi Dimensi Kalam Dan Perilaku Berdagang Pedagang Kaki Lima Di Padang Sumatera Barat.

14 Muhammad Ersya Faraby and Siti Inayatul Faiza, "Etos Kerja Pedagang Etnis Madura Di Pusat Grosir Surabaya Ditinjau Dari Etika Bisnis Islam,” JESTIT 1, no. 3 (2014): 178-93, https://doi.org/http://dx.doi.org/10.20473/vol1iss 20143pp\%25p. 
mendapatkan pahala dan mencari keridhoan Allah, sedangkan tujuan duniawi yaitu mencukupi kebutuhan hidup keluarganya. Penting disebut, sejarah Islam mencatat bahwa Nabi Muhammad Saw, istrinya, dan banyak sahabatnya adalah para pedagang yang aktif dan memiliki spirit kerja tinggi.

Fakta di lapangan menunjukkan, jumlah pedagang kaki lima tidak pernah menurun, bahkan cenderung meningkat. Situasi ekonomi yang tidak menentu dan sering munculnya kebijakan pemutusan hubungan kerja (PHK), menyebabkan bertambahnya pengangguran yang umumnya tinggal di kawasan perkotaan ataupun pinggiran kota. Fenomena ini banyak terjadi di sejumlah kota besar di Indonesia, terutama pada saat terjadi krisis ekonomi. Pada akhirnya, orang-orang yang terkena dampak PHK tersebut kemudian berpindah haluan dan memilih berbisnis sederhana yang memungkinkan dijalani, yakni sebagai pedagang kaki lima.

Spirit of life menunjukkan pemaknaan mendalam atas tugas manusia dalam memenuhi kebutuhan hidup, yang memiliki basis nilai keagamaaan guna menyelesaikan problem praksis kehidupan. Kaum PKL ini, meminjam term Ganzevoort, menerapkan practical theology, 15 karena mereka tidak menjadikan dogma teologi sebagai wacana atau perdebatan, akan tetapi lebih memahaminya sebagai kekuatan yang hidup dan mendorong mereka sebagai kaum beriman untuk berjuang mencari kehidupan yang baik.

\section{Religious Value}

Religiusitas memiliki lima dimensi, yaitu: keyakinan (ideologis), praktik agama (ritualistik), penghayatan (eksperiensial), pengetahuan agama (intelektual), dan pengalaman dan konsekwensi. Meskipun demikian, dalam praktek unsur yang menonjol tidaklah semuanya. Ada komunitas beragamayang kuat dimensi keyakinannya, di sisi lain ada kelompok yang kuat penghayatan, dan pada kasus lain ada yang menonjol pada sisi pengetahuan keagamaan. Dimensi keberagamaan sesungguhnya bermuara pada dua hal yang utama, yaitu kesadaran agama (religious consciousness) dan pengalaman agama (religious experience). Kesadaran merupakan kombinasi keyakinan dan pengetahuan

15 R. Ruard Ganzevoort and Johan H. Roeland, "Lived Religion: The Praxis of Practical Theology," International Journal of Practical Theology 18, no. 1 (2014): 91-101, https://doi.org/https://doi.org/10.1515/ijpt-2014-0007. 
keagamaan, sedangkan pengalaman merujuk pada praktek yang dihasilkan dalam kehidupan nyata.

Aspek religious consciousness yang menonjol dari pedagang kaki lima adalah sikap tawakal pada Allah Swt. Mereka menjalani usaha dengan niatan yang sungguh-sungguh untuk mencari penghidupan, namun mengenai hasil yang mereka akan diperoleh, mereka berserah diri pada Tuhan. Sebagaimana ditulis Hayat, para PKL melakukan aktifitas bekerja setiap harinya adalah bagian dari cara mereka mempertahankan diri untuk bisa menyambung hidupnya. Bagi mereka itulah cara yang bisa dilakukan sehingga mau tidak mau harus dijalankannya, walaupun dengan pendapatan yang hanya cukup digunakan untuk keperluan sehari-hari (subsistence). ${ }^{16}$ Fakta ini menunjukkan betapa rasa tanggung jawab itu dijalani sedemikian rupa oleh mereka dengan segenap harapan akan takdir/nasib baik yang didapat.

Data dari studi-studi yang ada menyebut bahwa para pedagang kaki lima itu rata-rata berpendidikan menengah ke bawah, yaitu SMP-SMA. Karenanya aspek pengetahuannya masuk kategori sedang, termasuk juga pengetahuan keagamaannya. Hal ini berpengaruh dalam membentuk sikap keberagamaan, yang terejawantah dalam praktek berjualannya. Para PKL menjajakan dagangannya dengan fasilitas yang ada, memberikan layanan kepada orangorang yang beraktivitas di sekitar lokasi, sehingga mereka dapat dengan mudah berbelanaja barang/kebutuhannya. Mereka berusaha menampilkan sikap dan memberikan layanan pada konsumennya sebaik mungkin. Dengan modal pemahaman keagamaan, mendorong perilaku seseorang untuk menjalankan aktivitas usaha dengan mengedepankan faktor kejujuran, etika, moral dan sangat menghargai orang lain. Dalam prakteknya, faktor-faktor tersebut dianggap sebagai kunci sukses dalam berinteraksi dengan lingkungan.

Pada umumnya mereka menjaga standar moral dalam aktifitas dagang. Studi Yuliana menyebutkan, variabel religiusitas berpengaruh terhadap pengembalian pembiayaan. Sebanyak 94 persen responden tetap menjalankan usaha dengan sabar dan memohon pertolongan Allah ketika usahanya mengalami kebangkrutan, terdapat 81,28 persen responden yang tetap

16 Muhammad Hayat, "Strategi Bertahan Hidup Pedagang Kaki Lima (PKL)," Sosiologi Reflektif 6, no. 2 (2012): 63-73, https://doi.org/http:ejournal.uinsuka.ac.id/isoshum/sosiologireflektif /article/ download/54/49. 
menjalankan usaha dan berpegang pada prinsip agama ketika banyak kegiatan usaha yang menyimpang dari ketentuan syariah, serta terdapat 94,47 persen responden yang membayar angsuran sesuai akad meskipun kondisi keuangannya sedang bermasalah. ${ }^{17}$ Fenomena ini menegaskan nilai-nilai religiusitas bekerja dengan baik.

Akan tetapi studi lain melaporkan perilaku PKL pedagang buah di Pasar Pagi Samarinda tidak memenuhi standar etika bisnis Islam karena bertindak tindak juru dalam hal penggunaan timbangan.18 Memang tidak mudah untuk membuat generalisasi tingkat religiusitas dalam hubungannya dengan aktifitas bisnis kaum pedagang kaki lima karena memang faktanya beragam. Namun setidaknya dari banyak studi, mereka pada dasarnya kelompok yang rentan, karena itu mereka selalu berusaha tetap eksis dan dapat terus berjualan. Maka secara umum, kalangan PKL berusaha berperilaku jujur sebatas yang mungkin mereka lakukan. Mereka tidak pelit menyampaikan informasi yang dibutuhkan pelanggan, suatu hal yang lumrah dilakukan kelompok yang mencari kehidupan. Sebab bilamana mereka tidak jujur, pastilah tidak akan berhasil membangun kepercayaan pada para pelanggan.

Aktualisasi nilai-nilai religius dalam tataran kehidupan praksis cenderung variatif, ditambah faktor-faktor sosio-kultural yang juga memberikan pengaruh terhadap tindakan atau perilaku umat Islam terutama dalam konteks kegiatan ekonomi. Dalam konteks ini, sepanjang para PKL dalam menjalankan usaha tertanam juga motivasi religius maka sudah dapat dikatakan sebagai bentuk living teologi karena nilai keagamaan menjadi sumber etos kerja yang dapat memberikan dorongan dan tuntunan makna terhadap perilaku ekonomi.

Mereka dapat dinilai memiliki "kesadaran yang hidup" karena kesungguhannya dalam berusaha dengan berbagai cara, baik berjualan di tempat-tempat umum, di trotoar, di sudut perempatan, di pinggiran mall, di tempat keramaian publik, ataupun di sekitar area perkantoran dan sekolah. Sebagian berdagang menggunakan gerobak, sebagian mendirikan tenda, took

17 Sa'adah Yuliana, "Pengaruh Faktor Ekonomi, Modal Sosial, Dan Religiusitas Terhadap Pengembalian Pembiayaan Murabahah Sa'Adah," Jurnal Ekonomi Pembangunan 13, no. 1 (2015): 10-20, https://doi.org/https://doi.org/10.29259/jep.v13i1.4846.

18 Darmawati, "Perilaku Jual Beli Di Kalangan Pedagang Kaki Lima Dalam Perspektif Etika Bisnis Islam (Studi Kasus Pedagang Buah-Buahan Di Kota Samarinda)," FENOMENA 4, no. 2 (2012): 127-38, https://doi.org/http://doi.org/10.21093/fj.v4i2.220. 
sederhana semi permanen, bahkan tidak sedikit yang menggelar dagangannya di pinggir-pinggir jalan atau trotoar jalan kota. Keberadaan PKL dapat menjadi solusi, karena menyediakan harga lebih murah, bukan saja membantu masyarakat yang berpenghasilan rendah, bahkan juga tidak sedikit masyarakat kelas menengah atau kelompok pekerja kantoran berbelanja pada pedagang kaki lima. Secara teologis, aktifitas mereka terpuji karena menghindari bermalasmalasan dan menjunjung tinggi bekerja, selaras dengan tuntunan al-Qur'an agar orang bertebaran di muka bumi dan mencari karunia Allah Swt (QS. alJumu'ah:10).

Para pedagang kaki lima yang berada di seputar tempat ibadah, tidak jauh dari masjid, makam-makam tujuan wisata religi, lebih beruntung karena nuansa religius didapat dengan turut mendengar azan setiap masuk waktu shalat. Disinilah letak hubungan bahwa suasana batin (inner life) dapat menimbulkan rangsangan dari dalam (inner drive) yang pada gilirannya mendorong etos kerja. Secara teoretik, Etos kerja sebagai tindakan konkret seseorang dapat didrive dari pandangan seseorang mengenai world view Islam tentang kehidupan yang menekankan kepada pencapaian kesejahteraan duniawi, kemerdekaan dalam berbuat dan berkehendak, dan nilai kerja itu sendiri. ${ }^{19}$

Karakter amanah (tanggung jawab) juga terlihat pada mereka. Umumnya para pedagang bertanggung jawab atas usaha dan pekerjaan yang telah dipilihnya tersebut. Biasanya mereka memiliki kesepakatan dengan orang yang memiliki lahan atau yang berdekatan dengan usaha para PKL. Tanggung jawab mereka dapat dilihat dari tugas menyediakan barang/kebutuhan masyarakat dengan harga yang wajar. Bahkan lebih dari itu, mereka juga tertib membayar retribusi yang dikenakan. Retribusi PKL (Rp. 4000/hari) yang telah ditempatkan pada Lokasi Binaan (Lokbin) yang tersebar pada beberapa lokasi di Jakarta Pusat, dalam satu tahun mencapai Rp. 813.904 .000 (2015). Untuk menghindari kecurangan pada pelaksana lapangan, sistem outo debet diberlakukan, untuk itu, PKL diwajibkan membuka rekening pada Bank DKI. Sumbangan PKL terhadap Pemerintah DKI Jakarta tidak kecil khususnya dalam penyerapan tenaga kerja. Pemerintah DKI Jakarta mengakui bahwa PKL sebagai tulang punggung perekonomian ibu kota. Rata-rata konsumsi masyarakat Jakarta 70\% dari

19 Abdul Jalil, “Teologi Wirausaha,” ISLAMICA: Jurnal Studi Keislaman 6, no. 2 (2014): 203, https://doi.org/10.15642/islamica.2012.6.2.203-214. 
penghasilannya, dan sekitar $60 \%$ belanja di kaki lima atau pedagang eceran. Sektor ini menyerap sekitar 2,5 juta orang pekerja. ${ }^{20}$

Nilai religiusitas lainnya, sebagaimana ditunjukkan hasil riset, para PKL itu memiliki kebiasaan untuk bersedekah. Niatan utamanya adalah untuk sekedar membantu famili, kolega, atau tetangga rumah, dengan besaran sesuai kondisi. Sebagaigama dimaklumi, dagangan mereka tidak selalu laris atau terjual habis. Seringkali sisa dagangan yang tidak laku itu yang diberikan kepada orang lain, dalam kondisi yang masih layak diberikan. Namun apabila ada rezeki lebih, mereka pun juga bersedekah dengan uang kepada orang yang memerlukan uluran tangan. Dari studi Ubaidillah dkk. terdapat pernyataan responden yang menarik dikutip, "Aku nek delok wong-wong orak duwe iku sa'ake, kadang tak wei duwet atowo siso dodolanku tapi mek sitik, seng penteng aku entok ganjaran ko Allah, iku wes ngawe aku puas, lan bantu membantu antar wong liyo kan perintah Allah".21

Gambaran di atas menunjukkan praktek keberagamaan yang apa adanya, tulus, penuh kesungguhan, dan semacamnya menandakan adanya gairah berbagi di kalangan mereka. Meskipun mereka tidaklah tergolong berlebih, kebersahajaan dan kedermawanannya merupakan bukti konkret hidupya etos religious. Jika kita gelar lebih banyak lagi data, akan terungkap lebih banyak lagi di berbagai tepat dengan bentuk yang kurang lebih sama. Sebagian suka bersedekah ke anak-anak, sebagian bersedekah ke masjid dan sebagian ke tetangga dekatnya. Fakta ini menjelaskan betapa semangat filantropi, tumbuh baik di kalangan mereka yang selama ini dikesankan sebagai kelompok yang kurang mampu.

\section{Solidaritas}

Salah satu bentuk living teologi pedagang kaki lima adalah solidaritas (ukhuwwah) mereka. Rasa persaudaraan adalah manusiawi, yang terbentuk

20 Hasanuddin, "Penataan Dan Pemberdayaan Pedagang Kaki Lima Pasar Tanah Abang," Jurnal Ilmiah Akutansi Dan Manajemen (JIAM) 15, no. 1 (2019): 59-70, https://jurnal.ubharajaya.ac.id/index.php/jiam/ article/ view/543.

${ }^{21}$ Ahmad Ubaidillah, Sri Mulyani, and Dwi Erlin Effendi, "Makna Keuntungan Bagi Pedagang Kaki Lima (Studi Pada Pedagang Kaki Lima Di Bangsri Jepara)," Jurnal Akuntansi $\begin{array}{llllll}\text { \& Investasi } & 14, & \text { no. } & 1 & \text { (2013): }\end{array}$ https://journal.umy.ac.id/index.php/ai/article/view/496. 
melalui pola komunikasi antar berbagai elemen masyarakat. Dalam teori sosiologi disebutkan adanya karakter yang berbeda antara warga desa dan kota. Hubungan sosial masyarakat perkotaan seringkali berpola solidaritas organik, yaitu hubungan antar orang per orang lebih didasarkan pertimbangan untung dan rugi. Dengan demikian, kecenderungan individualistis sangat terasa. Sebaliknya, masyarakat pedesaan umumnya memiliki solidaritas mekanik, yang mana pola hubungan sosialnya terjalin secara kekeluargaan, ditandai dengan semangat hidup berbasis gotong-royong. ${ }^{22}$

Kedua tipe solidaritas itu dapat berjalan paralel dalam kehidupan PKL. Hal ini terjadi karena posisi mereka ini adalah kelompok masyarakat yang tergolong marjinal yang tersisih dari arus kehidupan, selain juga tidak berdaya karena posisi tawar (bargaining position) mereka lemah dan acapkali menjadi obyek penggusuran atas alasan penertiban kota. Menghadapi situasi demikian, komunitas PKL membangun sistem solidaritas internal yang kokoh.

Studi PKL di lingkungan Masjid Al Akbar Surabaya menunjukkan, kelompok ini memiliki rasa ukhuwah yang tinggi di kalangan mereka. Salah satu kelompok yang ada bernama Paguyuban PKL Makmur yang dikelola warga Pagesangan dan menempati lahan kosong seluas 10.962 meter persegi di sebeah utara masjid. Ketika ada masalah, komunitas ini mengedepankan solidaritas groupnya sehingga mereka bisa bertahan. Strategi adaptasi dilakukan dengan menciptakan dan mengembangkan jaringan sosial sehingga keberadaannya tetap eksis. ${ }^{23}$ Di tempat lain, PKL yang mengalami relokasi, mereka tetap kompak dan bersama-sama menempati lokasi barunya. Salah satu kelompok pedagang yang direlokasi adalah pedagang kurma ke Yayasan Said Naum di Jalan KH. Mas Mansyur. Yayasan ini meminjamkan 1,8 ha lahannya dipergunakan untuk menampung PKL disekitar Pasar Tanah Abang yang dianggap menganggu dan menjadi biang kemacetan karena menepati trotoar dan sebagian badan jalan. Setelah direlokasi, dampaknya positif terhadap lancarnya arus lalu-lintas pada

22 George Ritzer, Teori Sosiologi Dari Sosiologi Klasik Sampai Perkembangan Terakhir Post Modern (Yogyakarta: Pustaka Pelajar, 2012), 145.

23 Bagus Fajar F., "Pedagang Kaki Lima Di Lingkungan Masjid Al-Akbar Surabaya: Strategi Adaptasi PKL Anggota Paguyuban PKL Makmur Pagesangan Untuk Tetap Berjualan Di Lingkungan Masjid Al-Akbar Surabaya," AntroUnairdotNet 4, no. 2 (2015): 186-204, http://journal.unair.ac.id/download-fullpapers-aun96511a3748full.pdf. 
lokasi tersebut. Di lokasi Yayasan Said Naum, tidak hanya pedagang kurma, tapi ada juga pedagang pakaian yang sebelumnya berdagang di Pasar Tanah Abang. ${ }^{24}$

Mereka memiliki solidaritas sosial yang baik, terutama di kalangan seprofesi. Meskipun mereka berjualannnya sama dan berderet di satu kawasan mereka tetap bisa hidup rukun dan damai. Kelompok ini memaknai kebersamaan dan imunitas nilai kelompok menjadi bagian penting cara mereka bersikap. Hal demikian menghidupkan sikap saling percaya (trust), yang terus mereka pelihara. Sebagai contoh, merujuk hasil riset Hayat, adalah apa yang dilakukan Bu Karti di depan Pasar Demangan Yogyakarta. Dia terbiasa meninggalkan dagangannya, baik sejenak ataupun agak lama, dan tidak ragu menitipkannya kepada Ibu Nur, koleganya berjualan. Saling membantu diantara sesama pedagang merupakan bentuk solidaritas sehari-hari. 25

Terkait dengan solidaritas para pedagang kaki lima yang merupakan pendatang, huungan solidaritas mekanik dalam kondisi yang tidak penuh. Artinya ketika mereka bergabung dengan sesame PKL asal pendatang, solidaritas ingroup nya menguat. Sebagai contoh kasus di kota Mataram, Lombok, ada semacam asosiasi etnisitas, misalnya kelompok yasinan asal Madura, perkumpulan Sunda, Paguyuban Jawa, namun sifat keanggotaannya tidak mengikat. Tetapi ketika mereka berhadapan dengan orang lain pola hubungannya adalah khas masyarakat kota, yakni solidaritas organik. Dalam teori 'ashabiyyah (baca: etnisitas) Ibn Khaldun dijelaskan bahwa manusia sulit terlepaskan dari faktor kesukuan. Namun kesukuan yang muncul di kalangan PKL asal pendatang tidaklah menguat, hanya sebagai bentuk kesamaan nasib di dunia perantauan belaka. ${ }^{26}$

Studi Faisal memperkuat hal tersebut, yaitu para usahawan memulai dengan konsep "menanam budi" yaitu memperbaiki hubungan baik dengan sesama manusia. Para PKL pendatang asal Jawa yang hijrah ke luar Jawa memiliki prinsip bahwa orang harus hidup berdampingan secara baik di manapun berada, juga kepada siapapun. Hal senada juga dimiliki kounitas etnis Cina yang Abang."

${ }^{24}$ Hasanuddin, "Penataan Dan Pemberdayaan Pedagang Kaki Lima Pasar Tanah

${ }^{25}$ Hayat, "Strategi Bertahan Hidup Pedagang Kaki Lima (PKL)."

${ }^{26}$ Ahmad Amir Aziz, Teologi Sosial Pedagang Kaki Lima: Studi Motivasi, Daya Tahan Berwirausaha Dan Hubungan Sosial PKL Asal Pendatang Di Kota Mataram (Mataram: LP2M IAIN Mataram, 2014). 
menjalankan usaha, yaitu adanya unsur kepecayaan dengan kolega dengan tetap mengelola usaha dengan sungguh-sungguh. Pada intinya dapat digarisbawahi, komunitas-komunitas tersebut memiliki unsur-unsur modal sosial seperti saling percaya, hubungan timbal-balik, dan jaringan kerja yang luas. ${ }^{27}$

Hubungan sosial pada tataran lebih luas juga diwarnai dinamika tersendiri. Di kota Kupang pernah terjadi gesekan antar PKL muslim yang pendatang sekaligus minoritas versus PKL Kristen sebagai warga setempat yang mayoritas. Hal ini berawal dari rasa cemburu pedagang kaki lima Kristen yang melihat keberhasilan pedagang kaki lima Islam. Kasus ini mencuat karena ada komunitas yang tidak memahami dan mengimplementasikan dengan baik makna hidup toleransi beragama. Akan tetapi karena tuntutan ekonomi dan keinginan kuat untuk berhasil berdagang namun belum tercapai, maka terjadilah kecemburuan sosial yang berujung konflik. ${ }^{28}$ Namun demikian pada akhirnya kasus ini tidak berlanjut berkat kesigapan pemerintah daerah dan tokoh-tokoh agama dalam menjalankan peran mereka guna menciptakan keharmonisan dan kerukunan umat beragama. Jika para tokoh agama sudah sealur dalam melihat suatu persoalan, maka masyarakat di bawah juga akan cepet reda. Fakta ini menegaskan bahwa dalam hubungan sosial selalu ada dinamikanya, yang apabila dapat terkelola dengan baik, tidak akan menciderai hubungan baik yang selama ini sudah terbangun.

\section{Tansformasi Living Teologi}

Sebagaimana ditegaskan di awal, living teologi mengarah pada bentuk konkret pengalaman berteologi dalam dinamika sosial. Karena berhadapan dengan masyarakat, maka living teologi memiliki ciri sosial atau kontekstual agar lebih fungsional dan dimengerti secara lebih jelas arah yang dituju. Dalam konteks Islam, ia dipahami sebagai wajah praksis agama dan yang lebih menekankan pengamalan dimensi-dimensi sosialnya, bukan untuk membuktikan kebenaran dirinya. Hal ini mengingat, ajaran Islam adalah ajaran yang otentik, yang tidak perlu banyak dibuktikan kebenarannya secara teoritis tetapi dengan

\footnotetext{
27 Muhammad Faisal, "Modal Sosial Usahawan Pendatang Di Kabupaten Takalar Provinsi Sulawesi Selatan," Sosiohumaniora 19, no. 1 (2017): 70-76, https://doi.org/10.24198/sosiohumaniora.v19i1.10331.

${ }^{28}$ Rinto Hasiholan Hutapea, "Dinamika Pedagang Kaki Lima Islam Di Tngah-Tengah Mayoritas Kristen," MARAMPA' 2 (2017): 183-97, https://osf.io/ctu5j/download.
} 
memperlihatkan kedinamisannya dalam kehidupan nyata. Selain itu, keimanan haruslah berdimensi sosial, karena ketika ia hanya bersifat personal berarti Islam telah terlepas dari kewajiban-kewajiban sosialnya.

William B. Parsons menggunakan istilah "Social Religion," untuk menyebut studi ilmiah sosial tentang agama, yaitu bagaimana ilmu-ilmu sosial telah mendekati fenomena agama serta peran mereka dalam pembentukan dan evolusi bidang yang dikenal sebagai studi agama secara akademik. Dalam pengantarnya, "Framing Social Religion," dia membuat dua perbedaan dalam hal bagaimana agama dulu dan hingga kini masih diteliti oleh bidang-bidang sosial: pendekatan reduksionisme dan pendekatan dialogis terhadap agama. Reduksionisme tidak membahas atau tidak tertarik pada kebenaran agama, tetapi sebaliknya menganggap fenomena itu sebagai produk imajinasi manusia. Sedangkan pendekatan dialogis mengadopsi sikap yang lebih simpatik terhadap agama, termasuk argumen teologisnya. ${ }^{29}$

Salah satu studi ilmiah sosial keislaman yang patut dirujuk untuk memperoleh gambaran bagaimana living Islam dan living teologi diporet adalah yang dilakukan oleh Magnus Marsden. Dalam bukunya, Living Islam: Muslim Religious Experience in Pakistan's North-West Frontier (2005), Marsden mengungkap Pakistan sebagai negeri yang tak terhindarkan dalam cengkeraman kaum Islamis yang fanatik dan bagaimana orang-orang ditekan dalam kehidupan sehari-hari mereka oleh para pengkhotbah reformis radikal. Amélie Blom yang meresensi buku tersebut menyatakan bahwa relevansi pernyataan Marsden jauh melampaui studi kasus yang dilakukannya. Jika menjadi seorang Muslim di Chitral Pakistan melibatkan proses yang dinamis dan kreatif, yang mencerminkan interaksi yang kompleks antara pengambilan keputusan, energi intelektual, debat dan diskusi kritis, dan tingkat emosi yang seimbang, maka ini merupakan tesis yang cocok untuk menjadi Muslim di banyak bagian lain Pakistan dan di tempat lain. Pembagian yang masuk akal, sejauh konsepsi penduduk desa Rowshan tentang berbagai cara menjadi Muslim, bukanlah "reformis" versus "liberal" tetapi "berpikiran terbuka" versus "berpikiran sempit". Pada akhirnya, "Muslim sejati” bukanlah seseorang yang menjalankan agamanya

29 Nickolas P. Roubekas, "Book Riview: Social Religion Edited by William B.Parsons.," Religious Studies Review 45, no. 2 (2019): 135-37, https://doi.org/ $10.1111 /$ rsr.13954. 
secara rutin, tetapi sebagai seseorang yang tulus, berbelas kasih, dan berkorban. 30

Poin terakhir di atas semakin menegaskan pentingnya intensitas amaliah sebagai wujud konkret kaum beriman. Dala konteks ini, teologi Islam tidak hanya merupakan asas fundamental, tetapi juga sekaligus merupakan cara pandang dan pola pemahaman umat atas realitas dan pembacaan atas pesan moral Islam itu sendiri. Suatu konstruk teologi tidak hanya memberi suatu cara pandang eskatologis, tetapi juga memberi implikasi sosiologis. Dengan demikian bangunan teologis memberikan muatan makna kehidupan seseorang secara utuh. Makna kehidupan tersebut akan memberikan pedoman dan arah terhadap aktifitas-aktifitas yang dilakukannya, sehingga menantang (challenging) dan mengundang (inviting) seseorang untuk memenuhinya.

Di sinilah teologi sebagai sebagai suatu refleksi teoretis atas ajaran keagamaan berperan determinan dalam mempengaruhi para penghayatnya untuk berubah dan menggerakkan perubahan. Konteks teologis dewasa ini lebih mengarah ke respon atas problem-problem kemanusiaan, bukan lagi seperti wacana era klasik yang asyik memperbincangkan persoalan filosofis-ketuhanan. Dewasa ini corak teologis yang dibutuhkan haruslah bersifat kontekstual. Ia tidak hanya mendasarkan pada pemahaman ajaran dan tradisi klasik yang sudah mengakar, tetapi juga mengakui keabsahan locus theologicus yang lain seperti pengalaman manusia zaman sekarang. Lebih dari itu bahkan ia diharapkan dapat bermetamorfosis untuk mampu menggerakkan nilai-nilai keimanan. Itulah keimanan fungsional sebagai landasan etik dan motivasi bagi setiap tindakan.

Berdasarkan alur pemikiran di atas, konsep living teologi menjadi niscaya untuk dihadirkan. Tentunya ia bukan berdiri sendiri tanpa ada kaitan dengan pembaharuan teologi dalam dunia Islam yang sudah berjalan sebelumnya. Living teologi lebih merupakan aktualisasi lebih lanjut dari pemikiran yang berusaha menggeser teologi tradisional yang bersifat teosentris menuju antroposentris. ${ }^{31}$ Teologi era sekarang dituntut untuk lebih humanis, dengan menyapa para penganutnya sebagai kaum beriman yang membutuhkan perhatian. Untuk kaum

30 Amélie Blom, "Magnus Marsden, Living Islam Muslim Religious Experience in Pakistan's North-West Frontier," South Asia Multidisciplinary Academic Journal 1, no. April (2019), https://journals.openedition.org/samaj/215.

31 Hassan Hanafi, Dari Aqidah Ke Revolusi Sikap Kita Terhadap Tradisi Lama, terj. Asep Usman Ismail, Suadi Putro, dan Abdul Raof (Jakarta: Paramadina, 2003). 
beriman sendiri, mereka juga dituntut menerjemahkan rasa keimanannya agar tetap hidup dalam rentag waktu perjalanan hidup secara dinamis.

Untuk melihat bentuk living teologi pada masyarakat muslim, setidaknya ada dua perspektif yang dapat digunakan. Hal ini tergantung pada situasi sosial yang hendak dipotret. Kedua perspektif ini dapat digunakan secara terpisah atau bersama sekaligus.

Pertama, akulturasi. Secara sederhana akulturasi dapat diartikan mengambil sejumlah unsur budaya baru serta mengubahnya sedemikian rupa sehingga unsur-unsur budaya baru tersebut terlihat seperti unsur budayanya sendiri. Dengan persepktif akulturasi ini kita dapat melacak proses dan hasil interaksi antara keyakinan-keyakinan teologis komunitas muslim dengan praktek kehidupan kesehariannya. Budaya-budaya baru apa yang didapat oleh suatu komunitas, yang kemudian diambilnya untuk disandingkan dengan pemahaman keagamaanya sehingga melahirkan bentuk/tradisi baru hasil interaksi keduanya. Sebagai contoh, komunitas pedagang kaki lima, mereka sering tanpa persiapan yang matang, hanya karena niatan ingin mendapat penghasilan, tanpa pengetauan manajemen usaha. Setelah mereka lama menekuni pekerjaannya, mereka mempunyai cara tersendiri dalam mengelola usahanya agar mendapatkan keuntungan. PKL menjadi manajer tunggal yang menangani usahanya, mulai dari: perencaaan, pengaturan, dan pengendalian usahanya, padahal fungsi-fungsi manajemen tersebut jarang atau tidak pernah mereka dapatkan dari pendidikan formal.

Pengalaman menarik pernah dilakukan pelatihan selama lima hari oleh Dinas Koperasi Usaha Mikro dan Perdagangan Kota Batu kepada para pedagang kali lima. Hasilnya para PKL itu diajak untuk menjajakan kulinernya di mall. Di sini mentalitas lama para PKL yang cenderung "pasrah," diakulturasikan dengan mentalitas baru yang "berani" dan "tampil beda". Untuk menghilangkan image rendah, sebutan PKL itupun diubah namanya dari Pedagang Kaki Lima menjadi "Pedagang Kreatif Lapangan". ${ }^{32}$ Proses ini membutuhkan penyerapan nilai lama, dari tradisi berjualan apa adanya di pinggir jalan, menuju tampil berjualan di

\footnotetext{
32 Irsya Richa, "Lokab Halokes Dari PKL Pinggiran Goes to Mall Di Festival Kuliner Kota Batu," Batu Times, 2019, https://batutimes.com/baca/205553/ 20191129/224600/lokab-halokes-dari-pkl-pinggiran-goes-to-mall-di-festival-kulinerkota-batu.
} 
dalam mall. Proses kreatif dan perubahan mindset mutlak adanya sebagai upaya transformasi etos bisnis yang lebih profesional.

Kedua, fenomenologi. Yaitu suatu perspektif untuk mempelajari suatu gejala sosial-budaya dengan berusaha mengungkap pengetahuan atau kesadaran pelaku mengenai eksistensinya, dunia yang digelutinya dan perilaku-perilaku dalam kehidupannya. Hal ini penting karena pemahaman mengenai "dunia" inilah yang dianggap sebagai dasar bagi pewujudan pola-pola perilaku manusia dalam kehidupan sehari-hari. Dengan memahami way of life pelaku, kita dapat memahami mengapa pola-pola perilaku tertentu diwujudkan, dan bukan perilaku-perilaku yang lain. Dengan perspektif fenomenologis ini kita tidak akan menilai kebenaran atau kesalahan paham jabariyah atau qadariyah yang dianut pelaku, karena yang dianggap penting bukan lagi benar-salahnya sebuah doktrin teologis yang dianut, tetapi konteks pemahamannya itu sendiri.

Sebagai contoh, disertasi Agus Prastya tentang Perlawanan Pedagang Kaki Lima. Penelitian tersebut hendak mengungkap makna dan tujuan perlawanan PKL terhadap Satpol PP dan memahami bentuk-bentuk perlawanan PKL terhadap Pemkot Madiun. Dari hasil risetnya diperoleh gambaran bahwa tujuan perlawanan itu adalah untuk menolak relokasi yang dianggap akan mematikan usaha para pedagang kaki lima. Adapun bentuk-bentuk perlawanan ada dua. Ada perlawanan secara tersembunyi dengan cara: hit and run, memberi mahar pada aparat, mencari dukungan LSM, dan member suap Satpol PP. Adapun perlawanan terang-terangan berupa: bentrokan dan gontok-gontok di jalan, membakar rombong dan memblokade jalan, sengaja menempati "red area" dan melakukan protes dan unjuk rasa. ${ }^{33}$ Contoh lainnya, studi Ubaidillah dkk tentang makna "keuntungan" bagi para PKL yang menyebut tiga makna yang muncul dari pengungkapan mereka, yaitu: (i) keuntungan materi dalam bentuk simpanan atau tabungan yang digunakan pula untuk memenuhi kebutuhan pribadi, (ii) keuntungan spiritual terlihat dari kemauan para pedagang kaki lima untuk tetap memperhatikan perintah Tuhan, (iii) keuntungan kepuasan batin karena bisa membuat orang lain senang melalui kesempatan berbagi. ${ }^{34}$

33 Agus Prastya, Perlawanan Pedagang Kaki Lima (PKL) Terhadap Kebijaka Relokasi Pemerintah Kota Madiun (Studi Kasus Upaya Mempertahankan Lapak Dalam Rangka Untuk Hidup) (Disertasi, Universitas Muhammadiyah, 2018), 202-208.

34 Ubaidillah, Mulyani, and Effendi, "Makna Keuntungan Bagi Pedagang Kaki Lima (Studi Pada Pedagang Kaki Lima Di Bangsri Jepara).” 
Dua perspektif dan contoh-contoh di atas menggambarkan bagaimana cara kerja akademis untuk memotret pengalaman hidup kaum beriman. Karena kompleksitas masalah yang ada, living teologi membutuhkan 2 ilmu bantu yang sangat penting, yaitu antropologi dan sosiologi. Keduanya dapat saling mengisi untuk mengungkap sisi-sisi pemahaman dan perilaku sosial manusia. Ilmu sosiologi an sich terkadang mengesampingkan orientasi subjektif sebagai salah satu faktor yang membentuk perilaku manusia, sementara perilaku sosial juga dipengaruhi oleh nilai dan norma. Teologi sebagai refleksi keimanan juga merupakan suatu susunan nilai, simbol, dan makna yang menjadi spirit of life.

Sebagaimana digambarkan pada sub $\mathrm{C}$ di atas, para pedagang kaki lima adalah orang-orag yang memiliki spirit of life yang kuat. Mereka melalui hariharinya dengan bekerja keras, pagi-siang-malam, untuk memperoleh penghasilan guna memenuhi kebutuhan keluarganya. Selain motivasi itu juga didorong oleh rasa tanggungjawabnya sebagai hamba Allah, yang mana mereka memaknai aktifitas kerjanya sebagai bagian dari ibadah. Hal ini menunjukkan inti religiusitas mereka sebagai muslim yang yang memiliki rasa ketundukan pada Yang Muaha Kuasa. Menurut Karen Amstrong, dalam hubungan nilai kepasrahan atau ketundukan secara essensial yang diharapkan untuk diberikan oleh setiap Muslim kepada Allah adalah seseorang yang menyerahkan segenap dirinya kepada Sang Pencipta Tunggal. ${ }^{35}$ Kepasrahan tersebut merupakan bagian dari kesadaran kaum beriman, yang dalam kehidupan keseharian para PKL tampak dalam rasa berharapnya atas karunia Allah dalam bentuk rezeki yang dihasilkan melalui aktifitas dagangnya. Mereka berharap demikian, karena tidak sedikit di sejumlah wilayah posisi kaum pedagang kaki lima rawan terkena relokasi yang dapat mengganggu kelancaran usahanya.

Manfaat living teologi terkait padagang kaki lima sebagai subyek kajian adalah sebagai berikut. Pertama, bagi komunitas PKL sendiri akan dapat lebih meyakinkan bahwa apa yang dilakukannya selama ini merupakan bagian dari tugas keagamaan yang memiliki dimensi transendental karena perannya sebagai khalifah di muka bumi, bukan sekedar tuntutan memenuhi kebutuhan hidup keluarga. Kedua, bagi para tokoh agama dapat berperan secara lebih intens

35 Karen Amstrong, Sejarah Tuhan: Kisah Pencarian Tuhan Yang Dilakukan Oleh Orang-Orang Yahudi Kristen Dan Islam Selama 4000 Tahun, terj. Zaimul Am (Bandung: Mizan, 2004), 199-200. 
melalui dakwah bil hal untuk lebih memberdayakan komunitas PKL karena posisinya sebagai kaum mustadh'afin. Ketiga, bagi aktifis kemanusiaan dapat menjadi medan transformasi sosial yang menantang guna mengangkat para pedagang kaki lima ke posisi yang lebih berharga.

Konteks berteologi ketika orang hendak membantu masyarakat yang membutuhkan perhatian dapat ditipologikan ke dalam tipe model berikut. Pertama, berteologi secara karikatif, dengan cara membantu orang lain secara langsung sesuai keperluannya saat itu, misalnya memberikan makanan kepada orang yang kelaparan atau memberikan pakaian. Kedua, berteologi secara reformatif, dengan cara memberikan sarana prasarana yang dibutuhkan orang lain, misalnya memberikan alat pancing atau sarana yang mendukung kelangsungan pekerjaan. Ketiga, berteologi secara transformatif, dengan cara mengubah struktur masyarakat menjadi lebih adil dan terbebas dari berbagai bentuk penindasan. Model yang ketiga ini melanjutkan misi yang kedua, dengan argument jika orang hanya diberi alat pancing, bagaimana jika dia tidak memiliki memiliki kolam atau akses untuk memasukinya?

Untuk dapat mengarah ke situ, secara metodologis, ada empat tahap yang seharusnya dilakukan, yaitu; (i) mendalami secara langsung situasi atau masalah sosial melalui observasi partisipatif, (ii) pemetaan sosial untuk menempatkan pengalaman tersebut ke dalam konteks masyarakat yang lebih luas, (iii) refleksi teologis untuk menganalisis realitas yang telah dikontruk dengan berbasis elan vital kitab suci, dan (iv) aksi-nyata sebagai perwujudan iman melalui kerja sosial.

\section{E. Penutup}

Sebagai suatu konsep yang sedang berkembang, living teologi mencoba untuk memposisikan dimensi teosentris dan antroposentris dalam kedudukn yang berimbang dan saling berhubungan. Sebagai hamba, manusia tidak dapat melepaskan ketergantungannya dengan Tuhan. Kehadiran Tuhan mengisi kesadaran Muslim dalam waktu kapanpun. Sebagai khalifah, manusia memiliki tanggungjawab moral untuk mengubah dirinya, masyarakat dan lingkungannya. Dengan demikian, ketaatan kepada Tuhan dimanifestasikan dalam bentuk yang lebih relevan terhadap kebutuhan dan tantangan masyarakat yang dinamis.

Melalui living teologi sebagai sebuah perspektif dapat digambarkan akualiasinya dalam kehidupan para pedagang kaki lima. Komunitas ini ada 
dimana-mana, di seluruh wilayah negeri. Mereka adalah kelompokyang berjuang untuk menghidupi keluarga dengan bekerja keras dan pantang menyerah, dengan tetap menjaga nilai-nilai religiusitas semisal bersikap sopan dan melayani pada konsumen, menjaga hubungan baik dan bahkan berderma sesuai kemampuannya. Moralitas yang relatif terjaga ini menyiratkan hidupnya kesadaran ketuhanan (God conciousness), yang dalam konteks PKL muslim, terefleksikan dalam pergulatan mencari rezeki yang halal.

\section{BIBLIOGRAPHY}

Abdurrahman, Moeslim. Islam Transformatif. Jakarta: Pustaka Firdaus, 1997.

Ahimsa-Putra, Heddy Shri. “The Living Qur'ān: Beberapa Perspektif Antropologi.” Walisongo 20, no. 01 (2012): 235-60. https://doi.org/http://dx.doi.org/ 10.21580/ws.20.1.198.

Amstrong, Karen. Sejarah Tuhan: Kisah Pencarian Tuhan Yang Dilakukan Oleh Orang-Orang Yahudi Kristen Dan Islam Selama 4000 Tahun. Bandung: Mizan, 2004.

Aziz, Ahmad Amir. Teologi Sosial Pedagang Kaki Lima: Studi Motivasi, Daya Tahan Berwirausaha Dan Hubungan Sosial PKL Asal Pendatang Di Kota Mataram. Mataram: LP2M IAIN Mataram, 2014.

Blom, Amélie. "Magnus Marsden, Living Islam Muslim Religious Experience in Pakistan's North-West Frontier." South Asia Multidisciplinary Academic Journal 1, no. April (2019). https://journals.openedition.org/samaj/215.

Darmawati. “Perilaku Jual Beli Di Kalangan Pedagang Kaki Lima Dalam Perspektif Etika Bisnis Islam (Studi Kasus Pedagang Buah-Buahan Di Kota Samarinda)." FENOMENA 4, no. 2 (2012): 127-38. https://doi.org/http:// doi.org/10.21093/fj.v4i2.220.

Faisal, Muhammad. "Modal Sosial Usahawan Pendatang Di Kabupaten Takalar Provinsi Sulawesi Selatan." Sosiohumaniora 19, no. 1 (2017): 70-76. https://doi.org/10.24198/sosiohumaniora.v19i1.10331.

Fajar, Bagus. "Pedagang Kaki Lima Di Lingkungan Masjid Al-Akbar Surabaya: Strategi Adaptasi PKL Anggota Paguyuban PKL Makmur Pagesangan 
Untuk Tetap Berjualan Di Lingkungan Masjid Al-Akbar Surabaya." AntroUnairdotNet 4, no. 2 (2015): 186-204. http://journal.unair.ac.id/ download-fullpapers-aun96511a3748full.pdf.

Faraby, Muhammad Ersya, and Siti Inayatul Faiza. "Etos Kerja Pedagang Etnis Madura Di Pusat Grosir Surabaya Ditinjau Dari Etika Bisnis Islam." JESTIT 1, no. 3 (2014): 178-93. https://doi.org/http://dx.doi.org/10.20473/ vol1iss20143pp\%25p.

Ganzevoort, R. Ruard, and Johan H. Roeland. "Lived Religion: The Praxis of Practical Theology." International Journal of Practical Theology 18, no. 1 (2014): 91-101. https://doi.org/https://doi.org/10.1515/ijpt-20140007.

Hanafi, Hassan. Dari Aqidah Ke Revolusi Sikap Kita Terhadap Tradisi Lama.Jakarta: Paramadina, 2003.

Hasanuddin. "Penataan Dan Pemberdayaan Pedagang Kaki Lima Pasar Tanah Abang." Jurnal Ilmiah Akutansi Dan Manajemen (IIAM) 15, no. 1 (2019): 59-70. https://jurnal.ubharajaya.ac.id/index.php/jiam/ article/ view/543.

Hayat, Muhammad. "Strategi Bertahan Hidup Pedagang Kaki Lima (PKL)." Sosiologi Reflektif6, no. 2 (2012): 63-73. https://doi.org/http:ejournal.uinsuka.acid/isoshum/sosiologireflektif/article/ download/54/49.

Hutapea, Rinto Hasiholan. "Dinamika Pedagang Kaki Lima Islam Di TngahTengah Mayoritas Kristen." MARAMPA' 2 (2017): 183-97. https://osf.io/ctu5j/download.

Jalil, Abdul. “Teologi Wirausaha." ISLAMICA:Jurnal Studi Keislaman 6, no. 2 (2014): 203. https://doi.org/10.15642/islamica.2012.6.2.203-214.

Khwaja, Jamal. Living the Qur'an in Our Time. New Delhi: Sage Publication, 2012.

Lacy, Creighton. "Book Reviews: Living Theology in Asia Edited by John C. England." Missiology An International Review 11, no. 4 (1983): 535-37. https://doi.org/https://doi.org/10.1177/009182968301100411.

Prastya, Agus. Perlawanan Pedagang Kaki Lima (PKL) Terhadap Kebijaka Relokasi Pemerintah Kota Madiun (Studi Kasus Upaya Mempertahankan Lapak Dalam Rangka Untuk Hidup). Malang: Universitas Muhammadiyah, 2018. 
Rahman, Fazlur. Islamic Methodology in History. Islamabad: Islamic Research Institute, 1965.

Richa, Irsya. “Lokab Halokes Dari PKL Pinggiran Goes to Mall Di Festival Kuliner Kota Batu." Batu Times, 2019. https://batutimes.com/baca/ 205553/20191129/224600/lokab-halokes-dari-pkl-pinggiran-goes-tomall-di-festival-kuliner-kota-batu.

Ritzer, George. Teori Sosiologi Dari Sosiologi Klasik Sampai Perkembangan Terakhir Post Modern. Yogyakarta: Pustaka Pelajar, 2012.

Rizal, Toha Rudin. "Gambaran Konflik Bermatras Agama Di Indonesia (Problem Solving Berbasis Teologi Transformatif)." El-Hekam 1, no. 1 (2016): 43. https://doi.org/10.31958/jeh.v1i1.336.

Robikah, Siti. "Membumikan Teologi Transformatif Penyetaraan Sosial Umat." Fikrah: Jurnal Ilmu Aqidah Dan Studi Keagamaan 5, no. 2 (2017): 377-402. https://doi.org/http://dx.doi.org/10.21043/ fikrah.v5i2.2066.

Roubekas, Nickolas P. "Book Review: Social Religion Edited by William B.Parsons." Religious Studies Review 45, no. 2 (2019): 135-37. https://doi.org/ 10.1111/rsr.13954.

Sarkar, Anita. "We Live in a VUCA World: The Importance of Responsible Leadership." Development and Learning in Organizations 30, no. 3 (2016): 9-12. https://doi.org/10.1108/DL0-07-2015-0062.

Suratman, Junizar. Kalam Dan Etos Dagang Refleksi Dimensi Kalam Dan Perilaku Berdagang Pedagang Kaki Lima Di Padang Sumatera Barat. Jakarta: SPS UIN Syarif Hidayatullah, 2019. http://repository.uinjkt.ac.id/ dspace/bitstream/123456789/48607/1/JUNIZAR SURATMAN.pdf.

Tasmuji. “Teologi Transformatif Jaringan Islam Liberal.” Teosofi: Jurnal Tasawuf Dan Pemikiran Islam 1, no. 2 (2015): 251. https://doi.org/10.15642/ teosofi.2011.1.2.251-269.

Ubaidillah, Ahmad, Sri Mulyani, and Dwi Erlin Effendi. "Makna Keuntungan Bagi Pedagang Kaki Lima (Studi Pada Pedagang Kaki Lima Di Bangsri Jepara).” Jurnal Akuntansi \& Investasi 14, no. 1 (2013): 65-77. https:// journal.umy.ac.id/index.php/ai/article/view/496.

Walters (ed), James. Religious Imagination: How Narratives of Faith Are Shaping Today's World. London: Gingko Library, 2018. 
Yuliana, Sa'adah. "Pengaruh Faktor Ekonomi, Modal Sosial, Dan Religiusitas Terhadap Pengembalian Pembiayaan Murabahah Sa'Adah." Jurnal Ekonomi Pembangunan 13, no. 1 (2015): 10-20. https://doi.org/https:// doi.org/10.29259/jep.v13i1.4846.

Zuhri, H. "Living Islam: Apa Dan Mau Ke Mana?" Living Islam Journal of Islamic Discourses 1, no. 1 (2018): 1-30. https://doi.org/https:// doi.org/10.14421/lijid.v1i1.1530. 
